\title{
REGIONÁLIS SPECIALIZÁCIÓ ÉS A FELDOLGOZÓIPARI TEVÉKENYSÉG VÁLTOZÁSA
}

\author{
(Regional Specialization and Change \\ of Manufacturing Activity)
}

\section{RÉDEI MÁRIA - JAKOBI ÁKOS - JENEY LÁSZLÓ ${ }^{1}$}

Kulcsszavak:

integrálódás feldolgozóipar térbeli változása regionális specializáció ágazati koncentráció

A tanulmány célja bemutatni a hazai ipari tevékenység változását az átmenet idöszakában a foglalkoztatás, az értékesités és az exportértékesités alapján. A ternelés specializálodásának és térbeli változásának jellemzöi miként követik a nemzetközi fejlödést és játszanak szerepet a centrum-periféria esetekben. Igazolni, hogy a magas jövedelmü régiók tolódnak a magas termelékenységet jelentỏ ágazati tevékenység felé, míg az alacsonyabb jövedelemmel rendelkezö régiókban a munka-intenzív termelés felé.

\section{Bevezetó}

A csatlakozásra váró országok többségében a gazdaság térbeli terjedésének új dinamikája valósult meg. Különösen azokon a helyeken tapasztaltak nagyfokú és gyors változást, amelyek a stratégiai jelentőségü piacokhoz közel fekszenek. Felmerül a kérdés, vajon a változások mennyiben részei az európai integrációnak, és mit jelentenek az országon belüli felzárkózásban?

A kutatás abból indult ki, hogy

- az 1990-es évekbeli regionális gazdasági változások egyik magyarázó eleme a hazai feldolgozóipari tevékenység térbeli és összetételi eltolódása.

- tesztelni a gazdaságföldrajz nemzetközi tendenciáit Magyarországon.

A világban a gazdaság térbeli helyzete többféle módon változik:

1) az újfajta ipari tevékenységek új helyeken (green field típusú) telepednek meg, ami Magyarországra nemzetközi összehasonlításban is jellemző eset (Regional Forum UNIDO 2000);

2) a régi ipari térségek az új kihívásokra tevékenységük módosításával (brown field típusú) válaszolnak.

A kutatás során választ kerestünk arra is, hogy egy átmeneti térség integrálódása mennyiben új földrajzi helyek ${ }^{2}$ gazdaságba történỏ bekapcsolódása útján ment végbe (shift pattern), mennyiben specializálódás útján (share pattern).

\section{Regionális specializálódás elméleti megalapozása}

A gazdasági integrálódás hatását igazoló kutatási eredmények azt erősítik meg, hogy a kereskedelmi akadályok megszünése, a szabad kereskedelem kibontakozása, egyes tevékenységek mások rovására történő növekedését okozzák. Hatásaként 
egyes helyeken a termelési szerkezet átalakításában látnak megoldást, másutt megszüntetik és új földrajzi helyekre helyezik át a termelést. A változás mind a termelés, mind a munkaerỏ együttes vagy egyenkénti elmozdulásával lehetséges. A gazdaság és a regionális szerkezet változásait azért tudjuk jól követni a feldolgozóiparban, mert a termelés helyi forrásoktól független, és képzetlen vagy alacsonyan képzett munkaerőt használ fel, akik könnyen mobilizálhatók.

A gazdaságfejlődési ciklus szerint a munkaerő-igényes tevékenységet a minél több tudást beépító hozzáadott értéket termelö gazdaság váltja fel. Az egyes vállalkozásokban is követhető a munkaerö-intenzív tevékenység után a tudás magasabb szintű felhasználása. ${ }^{3}$ A gazdasági integrálódás egyfajta nemzetközi „tükröt” mutat a hazai gazdaság szereplőinek, ami „,kiválogatja” azokat az ágazatokat, amelyek az internacionális gazdaságban is versenyképes feltételekkel rendelkeznek, és maga a befektető is úgy véli, ezeken a helyeken jobban megtérül a tőke, a tudás. Ezzel egyes ágazatok és térségek az átalakulás nyerteseivé válnak, mások veszteseivé, és aktív védekezésként más gazdasági környezetbe helyezik át tevékenységüket (Nemes Nagy 2000).

A neoklasszikus megközelítés szerint a termelés hatékonyságának különböző természeti és támogatási lehetỏségei, illetve azok egymáshoz viszonyított termelési költségei, komparatív előnye magyarázzák a specializáció eseteit. A komparatív előnyök alapján a tevékenységeknek olyan térbeli cseréje valósul meg, ami a specializáció irányába hat. Azok a kevésbé versenyképes vállalkozások, amelyek a termelés áthelyezése mellet döntenek, a régiók közötti közeledéshez és nem a polarizációhoz járulnak hozzá. Az elmélet, az iparágak közötti (intra-industry) munkamegosztással magyarázza a folyamatokat (Lengyel 2000). A későbbi kutatások során az összehasonlító előny nem bizonyult elegendő magyarázó erőnek, új elméletek születtek.

$\mathrm{Az}$ „új gazdaság” földrajzi elmélet a tevékenységek agglomerálódásához tér viszsza, és a mennyiségből a minőségbe történỏ átmenettel magyarázza a specializálódás jelenségét. Ezeknek az elméleteknek az a közös jellemzöje, hogy a fejlett országokban a termelés növekvő hányada iparágon belüli (inter-industry) munkamegosztásban történik, amely kis számú és egymáshoz közeli termelési egységekben szervezödik. Ezért az ,új gazdaság” az infrastrukturális hálózatoknak és a nemzetközi üzletmenet müködésének nagy jelentőséget tulajdonít, mert ebben képes a hozzáadott érték termék növelö hatása valósan kibontakozni. A hálózati szerveződés a rugalmas piaci alkalmazkodást, a keresletre és a kínálatra adott gyors válaszokat nagymértékben elősegíti.

A harmadik elmélet az új kereskedelmi modell, mind az ágazatközi, mind az ágazatokon belüli munkamegosztást lényegesnek tekinti. Az első fázisban a központi helyek kínálják a legtöbb lehetőséget, ezért kevés helyen, többnyire a centrumban történik a beruházás, ami a környék munkaerövonzásával jár együtt. A termelés felfutásával a munkaerỏ ára gyorsan emelkedik, a költségek csökkentésére két mód kínálkozik: vagy nettó exporttermelő részegy ség lesz, és intermediereket gyárt, ami specializációhoz vezet, vagy olcsóbb munkaerỏ után néz egy másik régióban. Rit- 
Rédei Mária - Jakobi Ákos - Jeney László :

Regionális specializáció és a feldolgozóipari tevékenység változása.

Tér és Társadalom 16. évf. 2002/4. 87-108. p.

kán fordul elö a közbülső változat, miszerint magát a termelés költségeit csökkentik, pl. technológiaváltással, ezzel a szállítási költségek nem jelentenek telepítési tényezőt.

A hagyományos elméleteket az 1980-as években kezdték helyettesíteni a szállítási költség modellel, amit Krugman kiegészített az ún. intra-industry elmélettel. A gazdasági feltételezéseket versenyhelyzetben képzelte el és kettős feltételezéssel élt:

- A hálózati elemek költségeit megtakarítják (klaszteresedés). Ezért a nagy és fejlett régiók kapnak kiemelt figyelmet a stratégia építés során, valamint azok, amelyek jó piaci helyzetben vannak. A cégek arra törekszenek, hogy kevés földrajzi helyen indítsák el tevékenységüket, ezzel elérhetőséggel rendelkeznek, és kapcsolataik alkalmasak egy export alapú gazdaság kiépítésére.

- Azzal, hogy a határok átjárhatókká váltak, megvalósult az áruk szabad áramlása, a földrajzi hely jelentösége tovább nőtt. Valamint a szállítási költségek mérséklödése, az azonnali szállítás feltételei, a raktározás költségmegtakarításai a kisebb földrajzi távolsággal együttesen teljesülnek.

Krugman (1991) azt is igazolta, hogy a földrajzi elönyök a szállitási költségeket egy fordított U alakú eloszlás szerint határozzák meg, azaz a költségek növekedése egy ponton túl a földrajzi elönyök mérséklödését jelenti ${ }^{4}$. A szállítási költségek többlete egy ponton arra ösztönöz, hogy helyi fogyasztásra termeljenek, vagy a földrajzi helytöl független módon, pl. virtuálisan helyettesíthetö legyen. Az összefüggés elkülöníthető egy belépö, közvetitoó és szétáramló szakaszra. Abban az esetben, ha számottevö kereskedelmi korlátok állnak fenn, akkor a piachoz közeli régiók jutnak elönyhöz, a fejlesztés a centrumokban valósul meg a környékük rovására (belépő szakasz). Az integrálódás egy későbbi fázisában a logisztikai költségek mérséklődnek ugyan, de a cégek nem mutatnak hajlandóságot arra, hogy magasabb béreket fizessenek a központokban dolgozók számára, és megkezdődik a kiáramlás (közvetítő szakasz) $)^{5}$. A termelést oda kívánják helyezni, ahol már kedvezö tapasztalatokat gyüjtöttek, és a tevékenység át- vagy kihelyezését azokba a fejletlenebb régiókba készuilnek megvalósítani, ahol a termelési költségek alacsonyabbak, de magas hálózati költség ${ }^{6}$ rakódik a termékre (szétáramló szakasz). Ebben a szakaszban alakulnak ki a beszállítói kapcsolatok, indul meg a klaszteresedés.

Az elméletben felvetett egyik kérdés, miszerint a gazdasági tevékenységek a centrumokból a perifériák felé haladnak, a rendszerváltó országokban relevánsak. Jelen kutatás arra törekedett, hogy ezt a feltételezett „intermedier" költségközvetító helyzetet feltérképezze és felhívja a figyelmet a következő szakaszra. Várható a szállítási költségek növekedése, a szabad kereskedelmi hatások terjedése és a földrajzi hely szerepének megerösödése. Azt is megfogalmazhatjuk, hogy a regionális egyenlötlenségek tradicionális feléledése átmenetileg megkérdöjelezi a regionális politika hatékonyságát.

Az elméletek azt feltételezték, hogy a természeti erőforrásokhoz kötődő ágazatok, mint a bányászat, mezỏgazdaság nem képes áthelyezni tevékenységét, csak a feldolgozóipari termelés vagy a felhasznált munkaerő. Ezért került az elemzés közép- 
Rédei Mária - Jakobi Ákos - Jeney László :

Regionális specializáció és a feldolgozóipari tevékenység változása.

Tér és Társadalom 16. évf. 2002/4. 87-108. p.

pontjába a feldolgozóiparban foglalkoztatottak száma, jövedelme, az ipari értékesítés és az exportértékesítés. Azok a területek, amelyek munkaeröt igényelnek, emelkedő bérekkel számolhatnak, ami a közvetító szakasz egyik jellemzöje. Az egymásra rakodó hatások következtében "donor" és "fogadó" területek alakulnak ki, amelyek kapcsolata arra is alkalmas, hogy az egyirányú viszony akár ellenirányúvá is alakuljon. Ez a megfordulás jelenti a szétáramló szakasz kezdetét. PI. az elöállított termékbe a helyi gazdaságból beépített arány nö. A vállalat alacsonyabb fizetéssel rendelkezö bejáróterületeken vizsgálja a termelés áthelyezésének lehetőségeit, mivel az innen ingázók ott helyben, mint már betanult munkaerö állhatnak rendelkezésére. Egy idô után a fogadó régióban visszaesik a feldolgozóipar, a donor régióban koncentrálódik a tevékenység, és rövid virágzás után, a magas költségek ismét arra késztetik, hogy az alacsony fizetésekkel rendelkező, vagy a támogatásban részesülö más régióban keressenek helyet. A térbeli áthelyezödés döntései láncszerüen követik egymást. Ez a folyamat különösen gyors akkor, ha munka-intenzív és kevés állóeszköz felhasználásával tevékenykedỏ ágazatról (textil-, ruházati iparról) van szó. A termelés térbeli áthelyeződése ezzel követi a kereskedelmi költségeket. Ugyanis, ha a kereskedelem költségei túlságosan magasak, akkor a régió gazdasága helyi fogyasztásra termel, vagy közeledik a fogyasztói piachoz, ha alacsony, akkor távolabbi térségek ellátására is termel, és a termelés fokozása specializációt gerjeszt.

Kutatásunk azzal a hipotézissel élt, hogy a csatlakozásra váró országok esetében, az áru, töke és munkaerő szabad áramlásával, a gazdasági integrálódással ezek be fognak következni, és az ágazatközi (intra-industry) nemzetközi/globális és hazaillokális elönyök egymásra hatással lesznek.

E tekintetben gyors és folyamatos átrendeződés nem várható. A kontinensen mind a termelés, mind a munkaerő mobilitása elmarad az amerikai szinttől, ahol az említett hipotézisek többségét elöször igazolták. A feldolgozóipari tevékenység nem koncentrált, és az egy főre jutó jövedelmek regionális különbsége kisebb. Európában kisebbek a földrajzi távolságok, jobb az elérhetöség, és a munkaerö mobilitása elegendő. Különösen a határ menti területek azok, ahol a vállalkozások az ellátási típusú kapcsolataikat munkaerö növelése nélkül képesek bövíteni. A közlekedési csomópontok, illetve az e-gazdaság számára kedvezö adózási pontok önmagukban növekedési pólusokat generálnak. A csatlakozás gyorsitásával egyetértők támogatják a termelés kedvezöbb, (olcsóbb) gazdasági környezetbe történö elmozdulását. A csatlakozás ellenzői pedig attól tartanak, hogy olcsó munkaerö árasztja el a fejlett országokat, ezért a szabad mozgás fokozatait hangsúlyozzák.

Az elméleti feltételezések több országra történő igazolása, hogy a gazdasági integráció hatására miként alakul a földrajzi koncentrálódás, még korai szakaszban van. Krugman az USA és négy nagy európai állam összehasonlítása alapján azt bizonyította, hogy a textil-, ruházati és bőripar, a high tech alacsony földrajzi koncentrációt mutat.

Hanson azt igazolta, hogy az amerikai-mexikói határon kialakult integrálódás hatással van mind a piachoz közelebbi telepedésben (földrajzi elmozdulás), mind a regionális jövedelmi különbségek alakulásában (Hanson 1996). Az 1980-90-es 
Rédei Mária - Jakobi Ákos - Jeney László :

Regionális specializáció és a feldolgozóipari tevékenység változása.

Tér és Társadalom 16. évf. 2002/4. 87-108. p.

éveket elemzö munkák arra a következtetésre jutottak, hogy a legtöbb iparágban mégis földrajzi koncentrálódás megy végbe. Az említett U alakú változások igazolását, miszerint a gazdasági integrálódás korai szakaszában a központok veszítettek az ipari tevékenységből, és kiáramlás következett be, számos kutatás bizonyította. Szignifikáns eredményeket a minél részletesebb ágazati bontás esetén (pl. NACE 4 jegyü felosztás) kaptak. Minél részletesebben tudták áttekinteni az ipari tevékenységet, annál jobban volt igazolható a specializálódás. Vagyis a kiugrásszerú gyors térbeli változás csak a sokszor jelentéktelen ágazatokra igaz ${ }^{8}$.

Bizonyították, hogy a koncentráció vesztesei a kömyezetterhelö iparok voltak, mint a fa-, papír-, vegy-, gumi- és múanyagipar. Ha ez a fajta tevékenység adott helyen nőtt, akkor nemcsak a környezetszennyezést megelöző termelési költségek nőttek progresszivan, de a lakossági tiltakozás is ${ }^{9}$. Tény, hogy a képzetlen embereket alkalmazó, munka-intenzív és lassú fejlődést mutató ágazatok a fejletlen régiókba húzódtak.

A csatlakozásra váró országok esetében a munkaerőforrás és a nyersanyagigényes ágazatok súlya lassan mérséklödik (Inotai 1998). Az export gyors felfutása az ágazatokon belüli kereskedelemmel összefüggésben figyelhetó meg. A külföldi tőke érdeklődésének külkereskedelem-teremtő hatását több kutatás igazolta (JakabKovács-Oszlay 2000). Azt feltételeztük, hogy az ország szerkezetében bekövetkezett változások egyensúlyi folyamatnak tekinthetők. Kérdés, hogy ezek az ágazatok között, azaz horizontálisan, vagy az ágazaton belül, vertikálisan mentek-e végbe? Látni fogjuk, hogy a rendszerváltó országokban, Magyarországon is a horizontális átmenet jellemzö.

\section{A földrajzi hely és specializáció}

Az Unió országaiban az 1980-as években azt tapasztalták, hogy a politikai és gazdasági változások együtt jártak a földrajzi hely jelentőségének megnövekedésével. A kétpólusú világ felbomlásával új globális igények keletkeztek a kelet-nyugati kapcsolatok erösitésére. A rendszerváltó országokban ugyanakkor a keleti kapcsolatok jelentősége drámaian visszaesett. Tehát a „továbbítás” gyengült, átmeneti vákuum keletkezett. A transzfer, kapu és híd szerepekről az 1990-es évek második felében kezdtek említést tenni (Enyedi 1996). Egyes országokban annak voltunk tanúi, hogy korábbi történelmi kapcsolatok keltek életre, és ezek egybeestek az EU központi piacaihoz kötődő viszonnyal, és keletiről nyugatira módosultak a kereskedelmi partnereink. Mindez azt eredményezte, hogy az átmeneti országok keleti kapcsolatainak gyérülésével re-orientáció jött létre. Magyarország kilencvenes évei ebbe a változásba sorolhatók.

Kiemelten az EU felé irányuló kereskedelem járult ehhez a helyzethez, valamint a külföldi tőkeérdeklődés is nyugatról érkezett. A határhoz közeli térségek kritikus szerepe abban is megnyilvánult, hogy az állami szereplők itt valós alkura kényszerültek a nemzetközi szereplőkkel. Az országhatáron belül és nemzeti szabályok 
Rédei Mária - Jakobi Ákos - Jeney László :

Regionális specializáció és a feldolgozóipari tevékenység változása.

Tér és Társadalom 16. évf. 2002/4. 87-108. p.

között történt a nemzetközi gazdaság belépése (Sassen 1996). A távolság, ami kezdetben az üzleti bizalommal is összefüggött, az infrastruktúra minősége és a tudás, képességek átvétele játszotta a döntỏ szerepet. Az adaptációs készség vizsgázott, amely kétirányú felzárkózással valósult meg. A cél a nemzetközi környezetben való működés volt. A topológiai helyzetböl adódó külső körülmény azonban csak átmeneti elönyt jelentett, és növelte a regionális különbségeket. A megszerzett tapasztalatok gyorsan elavultak, érkeztek az újabb kihívások, a régi módszereket átadták a kevésbé helyzetben lévőknek. A kereskedelem és a hozzákapcsolódó szolgáltatások nagymértékben alakítják, specializálják a régiót a feladatok ellátására. A technológiai kapcsolatok mind elörevivő, mind visszafogó módon vehetnek részt a területi fejlődésben. A régi technológia képes blokkolni a jövőt, míg a modern technológia felzárkózást vár. A régiók helyzetbe kerüléssel képesek felemelkedni, és képesek lemaradni (Rédei 2002).

A határ menti területek a katonai támadástól való félelem és a határ gazdasági elszigetelő szerepe miatt a fejlesztésben sokáig mellözött régiók voltak. Nemcsak a határ túloldala nem jelentett vonzást, de a határ elválasztó szerepe is extra költségeket okozott, és a nyelv, a kultúra, az üzleti szokások további zavaró hatást jelentettek. Kevesebb vállalkozás települt ezekre a részekre. A liberalizációval a bérmunka jellegü termelés lépte át elöször a határt.

A határ elkülönítő szerepe az 1990-es években világméretekben módosult, amikor szabad kereskedelmi övezetek jöttek létre: NAFTA, Európai Gazdasági Tér, ma pedig már küszöbön a bővités folyamata. A gazdasági integráció sürgetőbbé vált, mint a politikai. De miként hatott mindez azokra a térségekre, amelyek nem a csatlakozó országok határán fekszenek. Érdekes ez abból a szempontból, hogy miként terjednek a kiegyenlítő hatások az ország belsejében. Az ország egyik felében lefutott tevékenység az ország másik részében lehet haladó, és ezzel szinte áthúzza a termelés váitozást az országon. A jó pozícióban lévő térségben pedig az egyes tevékenységek átadása elönnyel jár. Az outsourcing, a könyvjóváirás, mind a termelés hatékonyságát növelö tényező. Ha ezek a lehetöségek nem jelentenek megoldást, akkor következik be a vállalkozás migrációja (Mariotti 2001).

Az 1980-as években kifejlesztett új gazdaságföldrajzi elmélet szerint a határ menti régióba település a kereskedelmi költségeket csökkenti, és kedvezöbbé teszi a piaci elérhetöséget. Kezdetben ennek topológiai jelentőségét emelték ki, ezt követóen indultak el a gazdasági elemzések. A visszatekintő értékelések azt bizonyították, hogy sokszor azért indult el egy centrum-típusú fejlödés, mert adott cég odatelepült. Majd a koncentrálódással nőtt az egymás közötti tudásátadás, a tapasztalat és az üzleti kapcsolat növelte a stratégiai hely súlyát (Bernek 2000). A transznacionális vâllalatoknál kiemelt jelentósége van annak, hogy mások döntését elfogadják és követik. Azoknál a vállalkozásoknál, akik a termékek kiszállítására alapultak az is szempont, hogy nem kell elfogadtatni magukat, igazodni a szokásjellemzőkhöz, hanem a máshol már kialakult kiegészítő piaci szerepüket növelik az új környezetben.

A korábbi ipari struktúrában olyan ágazatok voltak többségben, amelyek kötődtek a természeti erőforrásokhoz. A csatlakozásra váró országok gazdaságának nemcsak 
új földrajzi helyválasztással, de együttmüködési bövüléssel is szembesülnie kell. Ez egy jelentős egész országra kiterjedő megújító erőt is jelent, mivel „az új edénybe új bor" is kerül alapon strukturális, tevékenységi változások valósulnak meg. A már kiépült fejlett piacok közelsége ezt a módosulást gyorsítja.

\section{A hazai ipar specializációjának és koncentráciojának változása a rendszerváltozás után}

Nyugat-Európában nagy teret nyert az iparágak térbeli koncentrációjának és a térségek ágazati specializációjának kvantitatív vizsgálata. Ezek alapján többen kimutatták (Hine 1990; Greenway-Hine 1991; Brulhart-Torstensson 1996; Amiti 1997), hogy az 1980-as és 1990-es években az iparágak számottevó részénél térbeli koncentrálódás zajlott le, ami az országok, térségek ipari tevékenységének specializációjával járt együtt.

A rendszerváltozás során a magyar iparban is radikális ágazati és területi átrendezödések mentek végbe. Mindez felveti annak a vizsgálatnak a szuikségszerüségét, hogy az iparágak térbeli szerveződésénél megfigyelhető-e a koncentráció, valamint jellemző-e az egyes megyék ipari specializációja ${ }^{10}$. A vizsgálathoz adatforrásként a Központi Statisztikai Hivatal megyei statisztikai évkönyveit használtuk, melyekből három megyei szintü, ágazati bontásban ${ }^{11}$ elérhető mutatót választottunk ki: az iparban foglalkoztatottak számát, valamint a teljes ipari értékesítés és àz ipari export értékesítés adatait. A mutatók a megyei székhelyü ipari szervezetek (vállalkozások) adatait tartalmazzák. Az értékesítés és az exportértékesítés adatai miatt a megyei székhelyủ vállalkozásokat kellett vennünk, függetlenül attól, h̨ogy azok telepei a megye területén vagy azon kívül vannak. A vizsgált időintervallum 1992-töl 2000-ig terjedt ${ }^{12}$.

A megyék ipari specializációjának és az iparágak térbeli koncentrációjának mérésére többféle index használható. Az indexek közül kettőt választottunk ki: az ún. Herfindahl indexet ${ }^{13}$, amely az abszolút specializációt, illetve koncentrációt méri, valamint az ún. Diszimilaritási ${ }^{14}$ indexet, amely a relatív specializációt, illetve koncentrációt méri ${ }^{15}$.

Herfindahl index (abszolút specializáció): $H_{j}^{S}=\sum{ }_{j}\left(S_{i}^{s}\right)^{2}$
Herfindahl index (abszolút koncentráció): $H_{i}{ }_{i}=\sum{ }_{j}\left(S_{i j}^{c}\right)^{2}$

Diszimilaritási index (relatív specializáció):

$D S R \quad j=\sum_{i}\left|S_{i j}^{S}-S_{i}\right|$

Diszimilaritási index (relatív koncentráció) ${ }^{16}$ :

$D C R \quad i=\sum j\left|S_{i j}^{c}-S_{j}\right|$ 


\section{A magyar megyék ipari specializációjának változása}

\section{Abszolút specializáció}

Magyarország megyéinek ipari specializációját a foglalkoztatás, az értékesítés, illetve az exportértékesítés szempontjából mértük meg. Általánosságban megállapítható, hogy az ipari foglalkoztatás esetében figyelhettük meg a legkisebb megyei abszolút specializációt, szemben az exportértékesítéssel, ahol a legerőteljesebb specializálódást tapasztaltuk.

Az 1992 és 2000 közötti vizsgált időszakban mind az ipari foglalkoztatást, mind az értékesítést és az exportértékesítést növekvő abszolút specializáció jellemezte. A növekedés mértéke a foglalkoztatás tekintetében volt a legalacsonyabb, míg legjelentösebben az ipari exportértékesítés esetében növekedett meg a Herfindahl index $\left(\mathrm{H}_{\mathrm{j}}^{\mathrm{S}}\right)$ értéke.

Az 1990-es évtized elején az élelmiszeripar még az egyik legfontosabb iparágazat volt. 1992-ben az élelmiszeripar adta az ipari foglalkoztatottak és az exportértékesítés 18-18\%-át, így a gépipar mögött a második legjelentösebb ágazat volt. Az élelmiszeripar az értékesítés tekintetében pedig már a legnagyobb részesedéssel rendelkezett, hiszen az évtized elején ez az ágazat az ipari értékesítésböl 23\%-kal részesedett. Az élelmiszeripar különösen a dél-alföldi megyékben volt domináns, ezért a Herfindahl index értéke Békés megyében és Csongrádban meghaladta a 0,35-öt, ami nem véletlen, hiszen Békés megye esetében az ipari értékesítés, Csongrád esetében pedig az exportértékesítés közel $60 \%$-át jelentette.

Az ezredfordulóra azonban az élelmiszeripar jelentösége lecsökkent az iparon belül, a foglalkoztatásban a bányászat, az értékesítésben a villamosenergia-ipar, az exportértékesítésben pedig a vegyipar mögött a legnagyobb aránycsökkenést szenvedte el. Ezért, bár több alföldi megyében ma is ez a legfontosabb iparág, egyik megye esetében sem tapasztalhattunk magas élelmiszeripari abszolút specializációt.

A kilencvenes évek elején az ipari értékesítés egyötödét a villamosenergia-ipar adta, amely az élelmiszeripar után a második legjelentősebb ágazat volt. A paksi atomerőmủnek köszönhetöen Tolna megye ipari értékesítéséböl 60\%-kal részesedett, ami a megyét 1996-ig erősen specializálttá tette. 2000-re azonban éppen a villamosenergia-ipar részesedése fogyatkozott meg a hazai ipari értékesítésböl, a korábbi 20\%-ról 9\%-ra. Bár Tolna értékesítésének ma is több mint felét adja, súlya e megyében is visszaesett, így ma már nem jellemző a magas abszolút specializáció.

Bár a kohászat és fémfeldolgozás országosan soha nem volt jelentős ágazat a vizsgált időszakban, az évtized közepéig domináns volt Fejér megye iparán belül, ami nagymértékben megnövelte a megye abszolút specializációját 1995-ig. Fejér ma is erősen specializált, azonban ma már a kohászat- és fémfeldolgozás háttérbe szorult az országosan is megerỏsödött gépipar mögött. 
Rédei Mária - Jakobi Ákos - Jeney László :

Regionális specializáció és a feldolgozóipari tevékenység változása.

Tér és Társadalom 16. évf. 2002/4. 87-108. p.

TÉT XVI. évf. 2002

Gyors ténykép

95

\section{1. ÁBRA}

A megyék abszolút ipari specializációjának változása 1992-2000 között

Magyarországon

(Change of Absolute Industrial Specialization in Hungarian Counties

between 1992-2000)

\begin{tabular}{|c|c|c|c|c|c|c|c|c|c|c|c|c|c|c|c|c|c|c|c|c|}
\hline $\mathrm{H}_{\mathrm{j}}^{\mathrm{S}}$ & & & oglal & lkozta & & & & & & rték & esít & & & & & xpor & tért & éke & esíte & \\
\hline Megyék & $\Xi$ & & 总 & : & 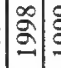 & oेई & $E$ & 2 & 声 & $\approx$ & 2 & 2 & : & 5 & 2 & 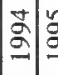 & & & 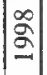 & 월올 \\
\hline Budapest & & & & & & & & & & & & & & & & & & & & \\
\hline Pest & & & & & & & & & & & & & & & & & & & & $\mathrm{GG}$ \\
\hline Fejér & & & & & & c & K & & $K$ & K & $\mathrm{G}$ & $\mathrm{G}$ & $\mathrm{G} C \mathrm{C}$ & $\mathrm{K}$ & $\mathrm{K}$ & \begin{tabular}{|l|l}
$\mathrm{K}$ & $\mathrm{K}$ \\
\end{tabular} & $\mathrm{K}$ & $\mathrm{G}$ & $\mathrm{G}$ & $\mathrm{GG}$ \\
\hline $\begin{array}{l}\text { Komárom- } \\
\text { E. }\end{array}$ & & & & & & & & & & & & & C & & & & $G$ & $G$ & & $\mathrm{G} G$ \\
\hline Veszprém & & & & & & & & & & & & & & & & & & & & \\
\hline Győr-M-S. & & & & & & & & & & & & $\mathrm{G}$ & G $\mathrm{C}$ & & & & G & $\mathrm{G}$ & $\mathrm{G}$ & $\mathrm{G} \mathrm{G}$ \\
\hline Vas & & & & & & & & & & $\mathrm{G}$ & $\mathrm{G}$ & $\mathrm{G}$ & $\mathrm{G} C \mathrm{C}$ & & $\mathrm{G}$ & GC & $\mathrm{G}$ & $\mathrm{G}$ & $\mathrm{G}$ & $\mathrm{GG}$ \\
\hline Zala & & & & & & & & & & & & & & & & & & 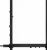 & & \\
\hline Baranya & & & & & & & & & & & & & & & & & & $\mathrm{G}$ & $\mathrm{G}$ & $\mathrm{G} G$ \\
\hline Somogy & & & & & & & & & & & & & $\mathrm{G}$ & & & & & $\mathrm{G}$ & $\mathrm{G}$ & $\mathrm{G} G$ \\
\hline Tolna & & & & & & & & $E$ & & \begin{tabular}{|l|l}
$E$ & 1 \\
\end{tabular} & & & & & & & & & & \\
\hline Borsod-A-Z. & & & & & & & & & & & & & & $\mathrm{V}$ & $\mathrm{V}$ & $\mathrm{VI}$ & $\mathrm{V}$ & $\mathrm{V}$ & $\mathrm{V}$ & \begin{tabular}{l|l}
$\mathrm{V}$ & $\mathrm{V}$ \\
\end{tabular} \\
\hline Heves & & & & & & & & & & & & & & & & & & & G & GC \\
\hline Nógrád & & & & & & & & & & & & & & & & & & $\mathrm{G}$ & & $\mathrm{G} G$ \\
\hline Hajdú-B. & & & & & & & & & & & & & & & & & & & & \\
\hline Jász-N-Sz. & & & & & & & & & & & & & & G & $\mathrm{G}$ & $\mathrm{GC}$ & $\mathrm{G} G$ & $\mathrm{G}$ & $\mathrm{G}$ & $\mathrm{G} C$ \\
\hline $\begin{array}{l}\text { Szabolcs- } \\
\text { Sz-B. }\end{array}$ & & & & & & & & & & & & & & & & & & & & \\
\hline Bács-K. & & & & & & & & & & & & & & & & & & & & $\mathrm{G}$ \\
\hline Békés & & & & & & & É & & & & & & & & & & & & & \\
\hline Csongrád & & & & & & & & & & & & & & $\underline{E}$ & & & & & & \\
\hline
\end{tabular}

* Szürke színnel az alacsony abszolút specializációjú (Herfindahl index $<0,15$ ) megyéket jelöltük. A magas abszolút specializációjú (Herfindahl index $>0,35$ ) megyéket a domináns iparág rövidítésével jeleztük, ahol $\mathrm{E}=$ =nergiaipar, É=élelmiszeripar, $\mathrm{G}=$ gépipar, $\mathrm{K}=$ kohászat és fémfeldolgozás, $\mathrm{V}=$ =egyipar.

Forrás: KSH alapján saját számítások.

Fejérhez hasonlóan mindvégig magas abszolút specializáció jellemezte BorsodAbaúj-Zemplén megye exportértékesítését is. Itt azonban a vegyiparnak sikerült máig megöriznie megyén belüli dominanciáját, így 2000-ben Borsod-AbaújZemplén megye az egyetlen, amely magas abszolút specializációját nem a gépiparnak köszönheti. 
Rédei Mária - Jakobi Ákos - Jeney László :

Regionális specializáció és a feldolgozóipari tevékenység változása.

Tér és Társadalom 16. évf. 2002/4. 87-108. p.

A rendszerváltás óta eltelt időszak legnagyobb nyertese a gépipar, amelynek mind az ipari foglalkoztatás, értékesítés, illetve mind az exportértékesítés tekintetében a legjelentősebben növekedett a részesedése. Az ipari foglalkoztatás és exportértékesítés esetében már 1992-ben is a legfontosabb ágazat volt, súlyát azonban még tovább növelte országosan az ipari foglalkoztatás esetében $21 \%$-ról $28 \%$-ra, az exportértékesítés esetében 27\%-ról közel 70\%-ra! Az ipari értékesítésben a rendszerváltás elején még csupán a negyedik helyen állt 13\%-os részesedéssel, mára azonban $44 \%$-os arányával az elsỏ helyre került.

Az ipari foglalkoztatás tekintetében ez az egyetlen iparág, amely a vizsgált időszakban magas specializációt eredményezett: 2000-ben Fejér megyében. Az ipari értékesítés esetében már több megyét is magas gépipari specializáció jellemez a kilencvenes évek közepétöl. A gépipar legjelentösebben a Dunántúlon erősödött meg. Az ipari értékesítés szempontjából magas (0,35 feletti Herfindahl index) abszolút gépipari specializációt elöször Vas megyében figyelhettünk meg 1995-ben. Késöbbiekben Fejér (1997), Györ-Moson-Sopron (1998), Somogy (1999), valamint Komárom-Esztergom megye (2000) ipari értékesítését is magas gépipari specializáció jellemezte.

Az exportértékesítés esetében még több megye specializálódott a gépiparra. JászNagykun-Szolnok megyének már 1992 óta magas a Herfindahl indexe, időközben magas gépipari specializáció jellemző az előbb említett Fejér, Győr-Moson-Sopron, Komárom-Esztergom, Somogy és Vas megye mellett Baranya, Heves, Nógrád és Pest megyékre is. 2000-ben 11 megyében volt magasabb a Herfindahl index értéke a 0,35-nél, amiből 10 esetben ez gépiparra specializálódást jelentett. Ez azt mutatja, hogy a rendszerváltás óta az ipari szerkezetátalakítás nyertese ágazati szempontból a gépipar, területileg pedig a Dunántúl lett.

Meg kell említeni azonban néhány megyét, amelyet igen alacsony abszolút fokú $(0,1$ alatti Herfindahl index) specializáció jellemez. A foglalkoztatás esetében több ilyen megye is elöfordul. Érdekesség, hogy Borsod-Abaúj-Zemplén megye ipari exportértékesítésének igen erőtejes vegyipari specializációja ellenére az ipari foglalkoztatás terén e megye mindvégig 0,1 alatti Herfindahl indexszel rendelkezett. Szintén a kilencvenes évek egészére alacsony abszolút specializációt figyelhettünk meg Veszprém és Zala megyékben. Veszprém több évben az értékesítés szempontjából is alacsonyan specializált volt, Zala megye pedig az egyetlen, amelyre az ezredfordulón az ipari értékesítésben (1998-tól) és exportértékesítésben (1997-töl) is alacsony specializáció volt jellemző. A rendszerváltás elején még Baranya és Nógrád megye ipari foglalkoztatása is alacsony abszolút specializációt mutatott, ez azonban később növekedett, 1999-től azonban ezúttal Csongráddal együtt Baranyára újra alacsony abszolút specializáció jellemzö.

A Herfindahl index értékeinek az 1992 és 2000 között eltelt nyolc év alatti változásairól elmondható, hogy a foglalkoztatás esetében egyik megyének sem változott meg jelentős mértékben az abszolút specializációja. A gépipar megyei foglalkoztatáson belüli erösödése leginkább Fejér és Somogy megye ipari specializációját 
Rédei Mária - Jakobi Ákos - Jeney László :

Tér és Társadalom 16. évf. 2002/4. 87-108. p.

növelte meg. Az index értéke pedig leginkább Békés megyében csökkent az élelmiszeripar korábbi súlyának mérséklödése folytán.

Az ipari értékesítés és exportértékesités szempontjából azonban már több megye abszolút specializációja erösen megnövekedett. Az értékesítésen belül az öt legspecializáltabb megyére (Fejér, Györ-Moson-Sopron, Komárom-Esztergom, Somogy és Vas) egyben a legnagyobb abszolút specializáció-növekedés is jellemzö. Az ipari exportértékesítésben az öt dunántúli megye mellett meg kell említeni Baranya, Heves és Pest megyéket is. Valamennyi esetben a növekedés hátterében a gépipar térnyerése húzódik meg.

Ugyanakkor az abszolút specializáció csökkenése már kevésbé volt feltủnö. Az ipari értékesítésen belül komolyabb mértékủ csökkenést egyik megye esetében sem tapasztalhattunk. Leginkább Bács-Kiskun, Békés, Szabolcs-Szatmár-Bereg, Tolna és Zala megyék Herfindahl indexe csökkent, Tolna megye (villamosenergia-ipar) kivételével valamennyi esetben az élelmiszeripar súlya visszaszorulásának köszönhetően. Az ipari értékesítésen belül szintén az élelmiszeripar korábbi dominanciájának mérséklődése tette kiegyenlítettebbé Csongrád megye ipari exportértékesítésének ágazati megoszlását, ami az abszolút specializáció jelentősebb mértékủ csökkenésével járt együtt.

\section{Relatív specializáció}

A megyék abszolút specializációja megmutatja, hogy az adott megye mennyire diverzifikált ágazati szerkezettel rendelkezik, azonban nem ad képet az országon belüli megyék közötti valódi munkamegosztásról. Egy olyan országban, ahol az ország egészében domináns egy ágazat, általában több megyében is jelentős részesedést ér el. Igazán az országon belül azon megyék tekinthetök specializáltnak, amelyek az országos átlagtól eltérỏ ágazati karakterủek. Annál nagyobb egy megye relatív specializációja, minél inkább eltér ágazati szerkezete az ország egészétôl. A következőkben az elözőekhez hasonlóan tekintsük át, hogy az ipari foglalkoztatás, értékesítés, valamint az exportértékesítés tekintetében hogyan alakult a magyar megyék relatív specializációja 1992 és 2000 között.

A megyék relatív specializációjának mértéke alapvetỏen két tényezőtöl függ. Egyrészt meghatározza magának az adott megyének az ágazati szerkezete, illetve az ország egészére jellemző ágazati megoszlás. Ha országosan egy nem túl jelentős iparág valamely megyében dominánssá válik, akkor nagy a relatív specializáció. A magas relatív specializáció ugyanakkor elöállhat úgy is, ha egy országosan jelentös ágazat súlya jelentéktelen az adott megyén belül. A következökben látni fogjuk, a magyar megyék mindkét esetre példát mutattak a kilencvenes években.

A relatív specializáció az abszolút specializációhoz hasonlóan mindvégig jóval alacsonyabb mértékủ volt az ipari foglalkoztatás esetében, amely a vizsgált időszakban még tovább csökkent. Jellemző az ipari foglalkoztatásban az alacsony relatív specializációra, hogy egyik évben egyetlen megye esetében sem haladta meg 
Rédei Mária - Jakobi Ákos - Jeney László :

Regionális specializáció és a feldolgozóipari tevékenység változása.

Tér és Társadalom 16. évf. 2002/4. 87-108. p.

a Diszimilaritási index $\left(\mathrm{DSR}_{\mathrm{j}}\right.$ ) értéke a 0,9-et. A legnagyobb relatív specializációt az exportértékesítés viszonylatában figyelhettük meg egészen 1998-ig, amikor az ipari értékesítés relatív specializációja több megyében annyira megnőtt, hogy meghaladta az exportértékesítés az évtized közepétöl egyébként általában csökkenő értékeit.

\section{2. ÁBRA}

A megyék relatív ipari specializációjának változása 1992-2000 között Magyarországon

(Change of Relative Industrial Specialization in Hungarian Counties between 1992-2000)

\begin{tabular}{|c|c|c|c|c|c|c|c|c|c|c|c|c|c|c|c|c|c|c|c|c|c|c|c|c|c|c|}
\hline $\operatorname{DSR}_{j}$ & \multicolumn{8}{|c|}{ Foglalkoztatás } & \multicolumn{9}{|c|}{ Értékesítés } & \multicolumn{9}{|c|}{ Exportértékesítés } \\
\hline megyék & $\tilde{2}$ & 2 & 泀 & 2 & ڤे & $\hat{2}$ & $\stackrel{\infty}{\beth}$ & $\hat{\xi}$ & O & 2 & 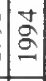 & 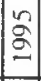 & $\stackrel{\circ}{2}$ & 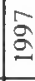 & $\stackrel{\circ}{2}$ & $\%$ & 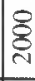 & 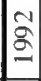 & 2 & 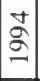 & $\begin{array}{l}\approx \\
2\end{array}$ & $\begin{array}{l}2 \\
2\end{array}$ & 2 & $\begin{array}{l}\infty \\
\Xi \\
\Xi\end{array}$ & $\stackrel{2}{2}$ & ह્ \\
\hline Budapest & & & & & & & & & & & & & & & & & & & & & & & & & & \\
\hline Pest & & & & & & & & & & & & & & & & & & & & & & & & & & \\
\hline Fejér & & & & & & & & & K & & $\mathrm{K}$ & $\mathrm{K}$ & $\mathrm{K}$ & G & & & & $\mathrm{K}$ & $\mathrm{K}$ & $\mathrm{K}$ & $\mathrm{K}$ & & & & & \\
\hline $\begin{array}{l}\text { Komárom- } \\
\text { E. }\end{array}$ & & & & & & & & & & & & & & & & & & & & & & & & & & \\
\hline Veszprém & & & & & & & & & & & & & & & & & & & & & & & & & & \\
\hline Györ-M-S. & & & & & & & & & & & & & & & & & & & & & & & & & & \\
\hline Vas & & & & & & & & & & & & G & $\mathrm{G}$ & & & & & & & $\mathrm{G}$ & $\mathrm{G}$ & & & & & \\
\hline Zala & & & & & & & & & & & & & & & & & & 1 & & & & G & $\underline{\underline{G}}$ & G & G & $\underline{\mathrm{G}}$ \\
\hline Baranya & & & & & & & & & & & & & & & & & & 1 & & & $\underline{\mathrm{G}}$ & & & & & \\
\hline Somogy & & & & & & & & & & & & & & & & & & & & & & & & & & \\
\hline Tolna & & & & & & & & & & $\mathrm{E}$ & $\mathrm{E}$ & $\mathrm{E}$ & $E$ & E & E & E & $\mathrm{E}$ & & & & & & $\mathrm{T}$ & $\mathrm{T}$ & $\underline{\mathrm{G}}$ & \\
\hline Borsod-A-Z. & & & & & & & & & & & & & & & & $\underline{G}$ & $\underline{G}$ & V & V & $\mathrm{V}$ & $\mathrm{V}$ & $\mathrm{V}$ & V & $\mathrm{V}$ & $\mathrm{V}$ & $\mathrm{V}$ \\
\hline Heves & & & & & & & & & & & & & & & & & & & & & & & & & & \\
\hline Nógrád & & & & & & & & & 1 & & & & & & & & & & & & & & & & & \\
\hline Hajdú-B. & & & & & & & & & & & & & & & & & (i & & & & É & Éc & $\mathrm{G}$ & Gi & Ci & (a) \\
\hline Jász-N-Sz. & & & & & & & & & & & & & & & & & & & & & & & & & & \\
\hline $\begin{array}{l}\text { Szabolcs- } \\
\text { Sz-B. }\end{array}$ & & & & & & & & & & & & & & & & & & & & & & & $\mathrm{G}$ & $\underline{\mathrm{G}}$ & $\underline{G}$ & G \\
\hline Bács-K. & & & & & & & & & & & & & & & & & & & & & & & & & & \\
\hline Békés & & & & & & & & & $\dot{H}$ & & & & É & É & É & C & $\underline{G}$ & $\mathrm{E}$ & É & $\hat{E}$ & $\mathrm{E}$ & É & $\hat{\mathrm{E}}$ & $\underline{\mathrm{G}}$ & G & $\mathrm{G}$ \\
\hline Csongrád & & & & & & & & & & & & & & & & & $\underline{\mathrm{G}}$ & É & $E$ & É & $\hat{E}$ & $\underline{G}] \underline{G}$ & $\mathrm{G}$ & $\underline{\underline{\mathrm{G}}}$ & $\underline{\mathrm{G}}$ & $\mathrm{G}$ \\
\hline
\end{tabular}

* Szürke színnel az alacsony relatív specializációjú (Diszimilaritási index $<0,4$ ) megyéket jelöltük. A magas relatív specializációjú (Diszimilaritási index $>0,9$ ) megyéket a domináns iparág rövidítésével jeleztủk, ahol $\mathrm{E}=$ =nergiaipar, É=élelmiszeripar, $\mathrm{G}=$ gépipar, $\mathrm{K}=$ kohászat és fémfeldolgozás, $\mathrm{N}=$ nemfémes ásványi termékek gyártása, $\mathrm{T}=$ =textilipar, $\mathrm{V}=$ =vegyipar. $\mathrm{Az}$ aláhúzott betük esetén a magas relatív specializációt az adott iparág országoshoz képest viszonylag jelentéktelen megyén belüli aránya okozza.

Forrás: KSH alapján saját számítás. 
Rédei Mária - Jakobi Ákos - Jeney László :

Regionális specializáció és a feldolgozóipari tevékenység változása.

Tér és Társadalom 16. évf. 2002/4. 87-108. p.

Az 1990-es évek első felére jellemző magas relatív specializációt az okozta, hogy egy-egy országosan nem túl jelentős iparág egy-egy megyében dominánssá vált. Ilyen volt például Fejér megye, amely a kohászat és fémfeldolgozás nagy súlya miatt az értékesítésben és az exportértékesítésben magas relatív specializációt ért el. Fejér az évtized második felében továbbra is magasan specializált megye maradt, 1997-től azonban már a gépipar „túlzott" részaránya miatt, ami kiszorította a korábban jelentős iparágat.

Fejérhez hasonlóan Vas megyében is az idöközben megerösödött gépipar okozta a magas relatív specializációt az ipari értékesítés és exportértékesítés tekintetében egyaránt a kilencvenes évek közepén. Az évtized végére azonban mind Fejérben, mind pedig Vasban lecsökkent a relatív specializáció, mivel a gépipar országosan is magas jelentöségre tett szert az iparon belül, így e két említett megye már nem tért el jelentős mértékben az országos ágazati szerkezettől.

1993-tól 2000-ig magas relatív specializációt figyelhettünk meg Tolna megye ipari értékesítésében is, amit a villamosenergia-ipar magas részaránya okozott. Érdekes módon az exportértékesítés esetében a textilipar magas részesedése játszott kulcsszerepet e megye magas Diszimilaritási indexében 1997-ben és 1998-ban. BorsodAbaúj-Zemplén megye ipari exportértékesítését pedig a teljes vizsgált időszakban a vegyipar magas részesedése miatt jellemezte magas relatív specializáció.

Az évtized elején több alföldi megye esetében az élelmiszeripar magas részesedése növelte meg a relatív specializációt. Az ipari exportértékesítés tekintetében Békés, Csongrád és Hajdú-Bihar megyében haladta meg a 0,9-es értéket a Diszimilaritási index, sőt Békésben az értékesítés esetében is.

A felsoroltakon kívül még megemlíthetö, hogy 1992-ben a nemfémes anyagok gyártása miatt magas relatív specializáció jellemezte Nógrád megye ipari értékesítését, az exportértěkesítés szempontjából pedig a vegyipari dominanciájú Zaláét, illetve az országos szintet meghaladó textilipari részesedése miatt Baranya megyéét is. Ezekben az esetekben azonban már 1993-ra 0,9 alá csökkent a Diszimilaritási index értéke.

A magas relatív specializációt nem csak az idézheti elö, hogy egy-egy ágazat „,elülreprezentált" egy megye iparában az országos súlyához képest, hanem akkor is elöfordulhat magas relatív specializáció, ha az ország egészében egy igen domináns ágazat jelentéktelen arányban szerepel egy adott megyében. A kilencvenes évek első felében még nem volt olyan iparág, ami ekkor országosan túlsúlyba került volna. Az évtized végére azonban ipari értékesítéséből és exportértékesítéséből a gépipar már országosan is olyan nagy arányban részesedik, hogy több megye magas specializációját már nem valamely más iparág nagy aránya, hanem a gépipar alacsony megyén belüli részesedése okozza. Ezért gyakran előfordult, hogy egy-egy megyében, amelyet az évtized elejétől folyamatosan magas relatív specializáció jellemzett, az évtized végére a Diszimilaritási indexe magas értékét már a gépipar súlyának elmaradása, és nem egy-egy ágazat országos szinthez képest magas részesedése idézte elö.

Ez a jelenség figyelhető meg az ipari értékesítés esetében 1999-töl Békés és Borsod-Abaúj-Zemplén, 2000-ben pedig Csongrád és Hajdú-Bihar megyékben. Mivel 
Rédei Mária - Jakobi Ákos - Jeney László :

Regionális specializáció és a feldolgozóipari tevékenység változása.

Tér és Társadalom 16. évf. 2002/4. 87-108. p.

az exportértékesítésben a gépipar részesedése még gyorsabban növekedett, mint az értékesítésben, így itt már az évtized közepétől elöfordul egy-egy megye esetében magas relatív specializáció a gépipar országosnál jóval kisebb részesedése miatt. 1996-tól Csongrád és Zala, 1997-től Hajdú-Bihar és Szabolcs-Szatmár-Bereg, 1998-tól Békés, 1999-ben pedig Tolna megye tartozik ide.

Már korábban említettük, hogy a foglalkoztatás tekintetében a megyék kevésbé térnek el az országos szinttől, ezért itt nem találtunk 0,9 feletti Diszimilaritási indexet a vizsgált időszakban egyik megyében sem. Ugyanakkor annál több megye esetében nem érte el a 0,4-es szintet az index értéke. Már a kezdetektöl alacsony relatív specializáció jellemezte Győr-Moson-Sopron, Hajdú-Bihar, Jász-NagykunSzolnok és Pest megyéket. A foglalkoztatás tekintetében a megyék relatív specializációjának jelentős csökkenését mutatja, hogy időközben csupán HajdúBihar megyének nött meg a Diszimilaritási indexe, 2000-ben pedig a maradék három megye mellett már meg lehet említeni Bács-Kiskun, Baranya, Heves és Komárom-Esztergom megyéket valamint Budapestet, ami azt jelenti, hogy az ezredfordulóra megduplázódott az alacsony relatív specializációjú megyék száma a foglalkoztatás területén.

Az értékesítés szempontjából Pest megye az egyetlen, amelyet mindvégig alacsony Diszimilaritási index értékek jellemeztek. Pest megyén kívül csupán GyörMoson-Sopron, Komárom-Esztergom és Veszprém megye, valamint Budapest ipari értékesítését jellemezte átmenetileg az országoshoz igen hasonló ágazati megoszlás.

Az exportértékesítés esetében (hasonlóan a foglalkoztatáshoz) az alacsony relatív specializációjú megyék számának növekedése látható. 1992-ben ezúttal is Pest megye említhető meg, 2000-ben ide sorolható Baranya, Györ-Moson-Sopron, Heves, Komárom-Esztergom, Nógrád, Somogy és Vas megye is. A felsorolt megyék elsősorban az országos átlaghoz hasonlóan magas gépiparuknak köszönhetik alacsony indexértéküket. Visszautalván a korábban elmondottakra, a megyék másik csoportjánál a gépipar részesedése viszont egyre inkább elmarad az ország egészére jellemzö extrém magas aránytól (2000-ben már közel 70\%), ami épp megnöveli Diszimilaritási indexüket. Ez azt jelenti, hogy 2000-re a megyék többségét az ipari exportértékesítésben vagy nagyon magas, vagy igen alacsony relatív specializáció jellemzi.

A relatív specializáció változásában tehát nemcsak a megye ágazati szerkezetének átalakulása játszhat szerepet, hanem az ország átlagos ágażati megoszlása is alakíthatja a Diszimilaritási index értékét. A relatív specializáció növekedését a legtöbb megye esetében éppen az idézi elö, hogy a gépipar súlya úgy megnőtt országosan, hogy attól egyre inkább elmarad az ágazat adott megyén belüli részaránya. Ez állapítható meg Zala megye ipari foglalkoztatása, Borsod-Abaúj-Zemplén megye értékesítése esetében, valamint Hajdú-Bihar megyében mind a foglalkoztatás, értékesítés és exportértékesités tekintetében. A relatív specializáció jelentősebb növekedésében csupán Szabolcs-Szatmár-Bereg az egyetlen, ahol nem a gépipari részesedés elmaradása, hanem egy másik ágazat, a textilipar megyén belüli súlyának nagymértékủ növekedése okozta a Diszimilaritási index növekedését. 
Rédei Mária - Jakobi Ákos - Jeney László :

Regionális specializáció és a feldolgozóipari tevékenység változása.

Tér és Társadalom 16. évf. 2002/4. 87-108. p.

A relatív specializáció nagy mértékủ csökkenésében a legtöbb megye esetében korábban jelentős iparág megyén belüli visszaszorulása játszik föszerepet. A foglalkoztatás tekintetében például a bányászat korábbi súlyának mérséklődése idézte elö Baranya, Heves és Komárom-Esztergom megyék Diszimilaritási indexének csökkenését, Bács-Kiskun és Békés megyék esetében pedig az élelmiszeripar visszaszorulása.

A relatív specializáció csökkenésében gyakran a megyén belüli folyamatok helyett az ország egészének változása játszik fontos szerepet. A gépipar országon belüli súlyának gyors növekedése miatt a korábban is magas gépipari részesedéssel rendelkező megyék ágazati megoszlása egyre jobban hasonlít az ország egészéhez. Erre találhatunk példát az ipari foglalkoztatás tekintetében Budapest, az értékesítésnél Jász-Nagykun-Szolnok, az exportértékesítésnél pedig ugyancsak Jász-NagykunSzolnok, valamint Nógrád megyék esetében.

\section{Az iparágak földrajzi koncentrációjának alakulása}

\section{Abszolút koncentráció}

Az iparágak földrajzi koncentrációját szintén a foglalkoztatás, az értékesítés és az exportértékesítés területén vizsgáltuk meg. Nagyvonalakban megállapitható, hogy a specializációhoz hasonlóan az abszolút koncentráció esetében is a foglalkoztatásnál találjuk a Herfindahl index $\left(\mathrm{H}_{\mathrm{i}}^{\mathrm{C}}\right)$ legalacsonyabb, az exportértékesítés esetében pedig a legmagasabb értékeit. Azonban miközben a megyék többsége a vizsgált időszakban egyre specializáltabb lett (föleg a gépiparra), az iparágak térbeli koncentrációja csupán az exportértékesítés esetében növekszik 1997-töl, az ipari foglalkoztatás és értékesítés esetében csökkent az ágazati koncentráció.

$\mathrm{Az}$ ágazatok abszolút földrajzi koncentrációja csökkenésének hátterében a korábban „túlsúlyos” Budapest iparon belüli szerepének csökkenése játssza a legfontosabb szerepet. 1992-ben az ipari foglalkoztatottak 29, az értékesités 36, az exportértékesítésnek pedig $38 \%$-a a fővárosra koncentrálódott. A rendszerváltás óta eltelt idők egyik látványos folyamata Budapest tercializálódása, ami együtt jár az iparon belül a vidék súlyának növekedésével. Idöközben az ipari foglalkoztatásból 8 , az értékesítésből 12 , az exportértékesítésböl pedig 22 százalékponttal csökkent a főváros részesedése, sőt az exportértékesítés tekintetében már Fejér (25\%) és GyörMoson-Sopron megye (18\%) mögött a harmadik helyre került.

Annak ellenére, hogy Borsod-Abaúj-Zemplén megye az egyetlen, amely jelentős mértékben specializálódik a vegyiparra, az ágazat mégsem e megyére, hanem a többi iparághoz hasonlóan Budapestre koncentrálódik. A vegyipari foglalkoztatás az egyetlen az iparágak közül, amely jelentős mértékü koncentrációt mutatott, igaz ez is csupán 1996-ig tartott. Az ipari értékesítésben és exportértékesítésben azonban mindvégig erősen koncentrálódott a fővárosra, aminek köszönhetően a Herfindahl index értéke a vegyipar esetében a teljes vizsgált időszakban 0,25 feletti volt.

A fa- és papíripar, valamint a gépipar esetében az 1990-es évek kezdetén még jelentös budapesti koncentrációt figyelhettünk meg az ipari értékesítés, és a gépipar esetében az exportértékesítés terén is. A vidék ágazaton belüli szerepének erősödé- 
Rédei Mária - Jakobi Ákos - Jeney László :

Regionális specializáció és a feldolgozóipari tevékenység változása.

Tér és Társadalom 16. évf. 2002/4. 87-108. p.

sével azonban már az évtized közepétől eltünt az erös abszolút koncentráció e két ágazat esetében, söt a gépipari foglalkoztatásra 1999 óta kifejezetten alacsony abszolút földrajzi koncentráció jellemzö.

3. ÁBRA

Az iparágak abszolút koncentrációjának változása 1992-2000 között Magyarországon

(Change of Absolute Concentration of Indusrial Branches between 1992-2000)

\begin{tabular}{|c|c|c|c|c|c|c|c|c|c|c|c|c|c|}
\hline $\mathrm{H}_{\mathrm{i}}^{\mathrm{C}}$ & \multicolumn{5}{|c|}{ Foglalkoztatás } & \multicolumn{4}{|c|}{ Értékesítés } & \multicolumn{4}{|c|}{ Exportértékesítés } \\
\hline Iparágak & 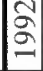 & 今| & |20 & $\mid \begin{array}{l}\mid \\
2 \\
2\end{array}$ & 웧웡 & 2 & 总糸 & 2 & बे 2 & क्षेळ్: & $\begin{array}{l}0 \\
\vdots \\
\vdots\end{array}$ & & है \\
\hline Bányászat & & & & & & & & & & & Já Já Já & & \begin{tabular}{l|l|}
$\mathrm{z}$ & $\mathrm{z}$ \\
$\mathrm{a}$ & $\mathrm{a}$
\end{tabular} \\
\hline $\begin{array}{l}\text { Élelmiszer- } \\
\text { ipar }\end{array}$ & & & & & & & & & & & & & \\
\hline Textilipar & & & & & & & & & & & & & \\
\hline $\begin{array}{l}\text { Fa- és } \\
\text { papíripar }\end{array}$ & & & & & & $\mathrm{Bp}$ & $\mathrm{Bp}$ & & & & & & \\
\hline Vegyipar & & & $\mathrm{Bp} B$ & & & 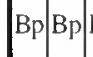 & $\mathrm{Bp}$ & $\mathrm{Bp} B$ & $\mathrm{Bp} B \mathrm{Bp}$ & $\mathrm{Bp}|\mathrm{Bp}| \mathrm{Bp}$ & $\mathrm{Bp}|\mathrm{Bp}| \mathrm{Bp}$ & & $\mathrm{Bp} B \mathrm{Bp}$ \\
\hline $\begin{array}{l}\text { Nemfémes } \\
\text { ásv. termé- } \\
\text { kek }\end{array}$ & & & & & & & & & & & & & \\
\hline $\begin{array}{l}\text { Kohászat és } \\
\text { fémfeldol- } \\
\text { gozás }\end{array}$ & & & & & & & & & & & $\mathrm{FeFe}$ & & $\mathrm{Fe}$ \\
\hline Gépipar & & & & & & $13 p$ & & & & B. & & & \\
\hline $\begin{array}{l}\text { Egyéb } \\
\text { feldolgozó- } \\
\text { ipar }\end{array}$ & & & & & & & & & & & & & \\
\hline $\begin{array}{l}\text { Villamos- } \\
\text { energia-ipar }\end{array}$ & & & & & & & & & & $\begin{array}{ll}\text { Gy } & \text { Bp } \\
\end{array}$ & $\mathrm{sp}$ & & \\
\hline
\end{tabular}

* Szürke sźnnel az alacsony abszolút koncentrációjú (Herfindahl index $<0,1$ ) iparágakat jelöltük. A magas abszolút koncentrációjú (Herfindahl index $>0,25$ ) iparágakat a domináns megye rövidítésével

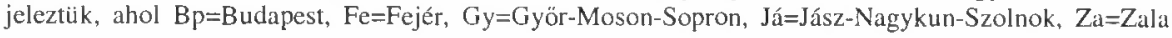
megye.

Forrás: KSH alapján saját szerkesztés.

Időközben több évben is magas földrajzi koncentráció jellemezte a bányászat, valamint a kohászat és fémfeldolgozás exportértékesítését. E két ágazat azonban az előzőektől ellentétben nem a fövárosra koncentrálódott. A kohászat és fémfeldolgozáson belül Fejér megye, a bányászaton belül pedig kezdetben Jász-NagykunSzolnok, 1997-től pedig Zala megye játszik kulcsszerepet. 
Rédei Mária - Jakobi Ákos - Jeney László :

Külön ki kell emelni a villamosenergia-ipart, amelynél az exportértékesítésben a többi ágazattól ellentétesen inkább növekvő koncentrációt tapasztalhattunk. Már 1992-ben a villamosenergia-ipari értékesítés koncentrálódott a legeröteljesebben, ekkor még Győr-Moson-Sopron megyére. 1993 óta azonban már ez az ágazat is a fövárosra koncentrálódik, miközben fokozatosan növekszik a koncentráció mértéke is. 2000-ben szinte teljes egészében (99\%) a föváros jelentette a hazai villamosenergia-ipari exportértékesítést.

Az ipari foglalkoztatás, értékesítés, illetve exportértékesítés közötti eltérő mértékủ ágazati koncentrációt érzékelteti az alacsony $(0,1$ alatti) értékủ Herfindahl indexszel rendelkezö iparágak száma. Az élelmiszeripar, textilipar, valamint az egyéb feldolgozóipari termékek elöállítása mind a három vizsgált területen kis mértékben koncentrálódik. A nemfémes anyagok gyártása már csak a foglalkoztatás és az értékesítés esetében mutat alacsony abszolút földrajzi koncentrációt. A foglalkoztatás tekintetében a felsorolt ágazatok mellett mindvégig alacsony koncentráció jellemezte a villamosenergia-ipart (az exportértékesítésben tapasztalt igen magas értéke ellenére), 1996 óta a kohászat és fémfeldolgozást, legújabban pedig a gépipart is.

Összességében a vizsgált időszakban a legnagyobb mértékben a gépiparnak (foglalkoztatás, exportértékesítés) és a vegyiparnak (foglalkoztatás, értékesítés) csökkent az abszolút földrajzi koncentrációja minden esetben a föváros korábbi túlsúlyának mérséklődése következtében. Igazán jelentös koncentrációnövekedés csak az energiaipari exportértékesítésben figyelhetö meg, amely szinte teljes egészében Budapestről származik. A foglalkoztatás és az értékesítés tekintetében csupán az élelmiszeripar esetében említhető meg az ágazat földrajzi koncentrációjának kis mértékü növekedése.

\section{Relatív koncentráció}

Az iparágak relatív földrajzi koncentrációja azt mutatja meg, hogy az adott ágazat földrajzi elterjedése mennyiben hasonló az ipar egészének földrajzi megoszlásához. Az abszolút koncentrációhoz hasonlóan az iparágak relatív földrajzi koncentrációja is a foglalkoztatás esetében a legalacsonyabb, míg az exportértékesítésnél találhatjuk a Diszimilaritási index $\left(\mathrm{DCR}_{\mathrm{i}}\right)$ legmagasabb értékeit.

A kilencvenes évek egészében magas relatív koncentráció jellemezte a bányászatot mind a foglalkoztatás, az értékesítés, illetve az exportértékesítés tekintetében. 1993-ig a Diszimilaritási index értékét mindhárom szempontból az okozta, hogy az ekkor leginkább vízfej szerepet betöltő föváros részesedése ezen ágazaton belül viszonylag alacsony volt. Az értékesítés esetében a későbbiekben is ez növelte meg az index értékét. A foglalkoztatás és az exportértékesítés tekintetében Budapest országos iparon belüli súlya annyira lecsökkent, hogy a magas Diszimilaritási index elsősorban olyan megyék miatt nő́tt meg, amelyekre a bányászat koncentrálódik. A foglalkoztatás esetében Borsod-Abaúj-Zemplén megye, az exportértékesítés területén pedig eleinte Jász-Nagykun-Szolnok megye, 1997-től pedig Zala megye orszá- 
Rédei Mária - Jakobi Ákos - Jeney László :

Regionális specializáció és a feldolgozóipari tevékenység változása.

Tér és Társadalom 16. évf. 2002/4. 87-108. p.

gos ipari súlyánál nagyobb ágazati részesedése játszott kulcsszerepet az ágazat magas relatív koncentrációjában.

\author{
4. ÁBRA
}

Az iparágak relatív koncentrációjának változása 1992-2000 között

Magyarországon

(Change of Relative Concentration of Indusrial Branches between 1992-2000)

\begin{tabular}{|c|c|c|c|c|c|c|c|c|c|c|c|c|c|c|c|c|c|}
\hline $\mathrm{DCR}_{\mathrm{i}}$ & \multicolumn{6}{|c|}{ Foglalkoztatás } & \multicolumn{5}{|c|}{ Értékesítés } & \multicolumn{6}{|c|}{ Exportértékesítés } \\
\hline Iparágak & 2 & ڤ人) & 2 & 2 & : & |ํㅟ & 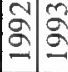 & 20 & : & 2 & 常: & हेंई & مी & शे & 위잉 & & : \\
\hline Bányászat & & & & & & & $\mathrm{Bp} B$ & $B p$ & & $\mathrm{Bp} B$ & $\mathrm{Bp}$ & $B p$ & a Bp Já & Já Já Jà & Já Za Za & $\mathrm{Za}$ & $|\mathrm{za}|$ \\
\hline $\begin{array}{l}\text { Élelmiszer- } \\
\text { ipar }\end{array}$ & & & & & & & & & & & & & & $\mid 35$ & & & \\
\hline Textilipar & & & & & & & & & & & & & & & & & \\
\hline $\begin{array}{l}\text { Fa- és } \\
\text { papíripar }\end{array}$ & & & & & & & & & & & & & & & & $\underline{\mathrm{Fe}}$ & $\mathrm{Fe}$ \\
\hline Vegyipar & & & & & & & & & & & $\mathrm{Bp} \mid \mathrm{Bp}$ & & & $\mathrm{Bp}$ & $B p B p$ & $B p$ & $\mathrm{Bp}$ \\
\hline $\begin{array}{l}\text { Nemfémes } \\
\text { ásv, termé- } \\
\text { kek }\end{array}$ & & & & & & & & & & $\mid B D$ & & & $\mathrm{re}=\mathrm{Ve}$ & $\mathrm{Ve} / \mathrm{Ve} \mathrm{V}$ & $\mathrm{Ve} \mathrm{Ve}$ & & $\mathrm{Fe}$ \\
\hline $\begin{array}{l}\text { Kohászat és } \\
\text { fémfeldol- } \\
\text { gozás }\end{array}$ & & & & & & & & & $\infty$ & & & & & $\mathrm{re} F$ & & & \\
\hline Gépipar & & & & & & & & & & & & & & & & & \\
\hline $\begin{array}{l}\text { Egyéb } \\
\text { feldolgozó- } \\
\text { ipar }\end{array}$ & & & & & & & & & & & & & $B n=2 i$ & & & & \\
\hline $\begin{array}{l}\text { Villamos- } \\
\text { energia-ipar }\end{array}$ & & & & & & & & & & & & & $y \mid$ & $5 p|0|$ & $\mathrm{Bp}$ & & \\
\hline
\end{tabular}

* Sziürke színnel az alacsony relatív koncentrációjú (Diszimilaritási index $<0,45$ ) iparágakat jelöltük. A magas relatív koncentráciojú (Diszimilaritási index $>0,85$ ) iparágakat a domináns megye rövidítésével

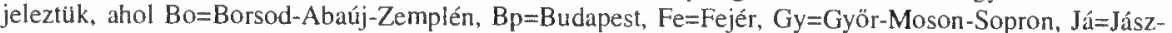
Nagykun-Szolnok, Ve=Veszprém, $\mathrm{Za}=Z$ Zala. Az aláhúzott betük esetén a magas relatív koncentrációt az adott megye országos össziparhoz képest viszonylag jelentéktelen iparágon belưli arânyá okozza.

Forrás: KSH alapján saját számítások.

Az ipari értékesítésnél a vegyipar, az exportértékesítés esetében a vegyipar mellett a villamosenergia-ipar szintén magas relatív koncentrációval jellemezhetö. Ezeknél az ágazatoknál a Diszimilaritási index magas értékét az idézte elö, hogy a föváros ágazaton belüli aránya jóval felülmúlta Budapestnek az ország iparán belüli súlyát.

Az évtized közepén az értékesítés és az exportértékesítés esetében a kohászatra és fémfeldolgozásra ugyancsak magas relatív koncentráció volt jellemzö. Itt a magas 
Rédei Mária - Jakobi Ákos - Jeney László :

Regionális specializáció és a feldolgozóipari tevékenység változása.

Tér és Társadalom 16. évf. 2002/4. 87-108. p.

indexértéket Fejér megyének az átlagosnál magasabb ágazaton belüli részesedése okozta.

A nemfémes ásványi anyagok, és a fa- és papíripari termékek exportértékesitése esetében azonban éppen az okozta a magas relativ koncentrációt, hogy az említett ágazatokon belül Fejér megye részaránya nagyon elmarad a megye össziparon belüli jelentős súlyától.

A tíz ágazatból azonban hat esetében a foglalkoztatásnál a Diszimilaritási index értéke 0,45 alatt maradt: élelmiszeripar, textilipar, fa- és papíripar, kohászat és fémfeldolgozás, gépipar és egyéb feldolgozóipar. Az értékesítés esetében már inkább csak az élelmiszer-, a gép- és textilipar esetében tapasztaltunk az évtized elején alacsony relatív koncentrációt, az évtized végére azonban egyre inkább növekedtek e tekintetben a Diszmilaritási index értékei. Az exportértékesítés esetében pedig a gépipar relatív koncentrációja alacsony, amely az ország össziparán belül egyre meghatározóbbá válik, így területi elterjedése is hasonlatos az ipar egészéhez.

A nyolc év alatt eltelt változásokat összegezve megállapíthatjuk, hogy a foglakoztatás és az értékesítés tekintetében a legnagyobb mértékben a bányászat relativ koncentrációja csökkent, amely már kevésbé koncentrálódik Komárom-Esztergom megyére. A Diszimilaritási index értékeinek legjelentősebb növekedése pedig annak tulajdonítható, hogy az országosan egyre fontosabbá váló Fejér megye az adott ágazaton belül nem képvisel jelentős arånyt. Ez utóbbi figyelhető meg a nemfémes anyagok és a vegyipar értékesítésében, valamint a vegyipari és a fa- és papíripari exportértékesítésben. Ugyanakkor a kohászat és fémfeldolgozás exportértékesítése éppen amiatt veszített relatív koncentrációjából, hogy az ágazaton belül jelentős Fejér megyének időközben megnövekedett az egész iparon belüli aránya.

\section{Összegzés}

A nyugat-európai tendenciákkal összehasonlítva megállapíthatjuk, hogy a térségek abszolút specializációja hazánkban is nött, ellenben az ágazatok abszolút koncentrációja viszont csökkent. Mind a specializációnál, mind pedig a koncentráció esetében a legkisebb változásokat az ipari foglalkoztatás esetében tapasztaltuk, míg a legradikálisabb átrendeződést az exportértékesítés esetében figyelhettük meg.

Általánosságban elmondható, hogy míg az abszolút specializáció jelentős mértékben megugrott, az abszolút koncentrăció kisebb mértékben csökkent. Az előbbi folyamat hátterében az áll, hogy különösen a dunántúli megyékben megjelent, illetve megerösödött a gépipar, amely a korábbi, gyengébb erősségü, több megyében tetten érhető élelmiszeripari dominanciát váltotta fel. Az abszolút koncentrációcsökkenés fő mozgatórugója pedig az a jól ismert folyamat volt, hogy a tercializálódó föváros a hazai iparban 1992-ig még markáns súlyát fokozatosan átadta a vidék megyéinek, ezzel csökkentve az iparágak abszolút koncentrációját.

A Diszimilaritási index segítségével mért relatív specializáció, illetve koncentráció értékei az abszolút viszonylattól eltérően viselkedtek. A relatív specializáció átlagosan csökkenö, míg a koncentráció növekedő tendenciát írt le. A relatív 
Rédei Mária - Jakobi Ákos - Jeney László :

Regionális specializáció és a feldolgozóipari tevékenység változása.

Tér és Társadalom 16. évf. 2002/4. 87-108. p.

specializáció csökkenését az okozta, hogy több megyén belül, s így országosan is a gépipar súlya egyre fontosabbá vált, a megyék iparszerkezete közeledett egymáshoz. A relatív koncentráció esetében megfigyelhető növekedési folyamat fö mozgatórugója, hogy a gépipar dominálta új ipari szerkezetben a legtöbb iparág földrajzi megoszlása egyre kisebb hatással van a teljes ipar földrajzi megoszlására, így egyre inkább el is tér attól.

A specializáció (vagy koncentráció) növekedését elöidézheti egy-egy ágazat (vagy megye) növekedése, de okozója lehet a korábban nem túl jelentós ágazatok (vagy megyék) leépülése is. Ugyanígy a specializáció (vagy koncentráció) csökkenése előállhat a korábban domináns ágazat (vagy megye) iparának csökkenéséböl, avagy egy azelött jelentéktelen ágazat (vagy megye) gyors növekedéséböl. Ehhez a Herfindahl és Diszimilaritási indexek és a tényleges ipari mennyiségi (foglalkoztatási, értékesítési, exportértékesítési) változásokat érdemes összevetni.

Az ipari foglalkoztatás, értékesítés, exportértékesítés azokban a megyékben nött leginkább, amelyek abszolút specializációja gyorsabb ütemben növekedett. A Herfindahl indexek változása és az ipari növekedés közötti korrelációs együtthatók mindhárom esetében 0,7 körüliek voltak. Ez azt jelenti, hogy a megyékben nem egy-egy korábban jelentéktelen ágazat leépülése, hanem a húzóágazatok (gépipar) megerösödése eredményezte az abszolút specializáció növekedését.

A relatív specializáció változása, illetve az ipari növekedés között már nem volt ilyen erös összefüggés. Mi több, az értékesítés és az exportértékesítés esetében a közepes erősségü korrelációs együttható negatív elöjelü. Ez azt mutatja, hogy azok a megyék növekedtek leginkább, amelyek képesek voltak lépést tartani az országos tendenciákkal, ami döntően a gépiparuk gyors növekedésének tudható be. Az alternatív ágazatokra szakosodó megyék pedig általában kisebb ipari növekedést könyvelhettek el.

$\mathrm{Az}$ ágazati koncentráció esetében az ágazat mennyiségi növekedése, illetve koncentrációjának változása között ritkán találtunk szorosabb összefüggést. Itt az abszolút koncentráció változása és az adott ágazat mennyiségi növekedése között inkább fordított összefüggés állapítható meg a foglalkoztatás és az értékesítés esetében. Ennek hátterében ugyancsak a gépipar áll, amely miközben a leggyorsabban növekedett, országosan egyre inkább szétterjedt, azaz csökkent a koncentrációja. Ez alól az exportértékesítés kivétel, ugyanis itt az egyre inkább fővároscentrikus villamosenergia-ipari export igen gyors növekedést ért el, ezért itt pozitív elöjelủ a korrelációs együttható.

A relatív specializáció változása pedig szinte semmilyen összefüggést nem mutat az ágazatok mennyiségi növekedésével, a korrelációs együtthatók ez esetben 0 körüliek.

Végezetül érdemes azt is megnézni, hogy a gyorsabban specializálódó megyék nagyobb gazdasági fejlődést értek-e el. Ehhez a megyék abszolút és relatív specializációját az egy före jutó GDP-jük 1994 és 2000 közötti változásával vetettük össze. A korrelációs vizsgálatokból kiderült, hogy a megyék abszolút specializációjának növekedése pozitív viszonyban áll a gazdasági fejlődésükkel, a 
kapcsolat erössége azonban közepes, csak az ipari értékesítés esetében figyelhetünk meg viszonylag szorosabb összefüggést $(r=0,6)$. A relatív specializáció változása és a gazdasági fejlődés esetében pedig szinte semmilyen összefüggés nem állapítható meg. Véleményünk szerint azonban a vizsgált hat év még túl rövid idő ahhoz, hogy egyértelmủ választ kapjunk a területi specializálódás hatékonyságának megítéléséhez. Úgy tünik a honi ipar rendszerváltás óta bekövetkezett ágazati és területi szerkezeti átrendezödése még nem zárult le, sőt a küszöbön álló európai uniós csatlakozás még újabb helyzetet teremthet a megyék és iparágak jövöbeni fejlődésében.

\section{Jegyzetek}

${ }^{1}$ A kutatás a PHARE ACE P98-1117-R projekt, „Európai integrálódás, regionális specializáció és ipari tevékenységek térbeli rendje a csatlakozásra váró országokban” címủ öt országra (Bulgária, Észtország, Magyarország, Románia és Szlovénia) kiterjedő összehasonlító elemzés keretében készült. A hazai kutatás vezetöje Rédei Mária egy. docens, ELTE TTK Regionális Földrajz tanszék (www.geogr.elte.hu/ref).

${ }^{2}$ Az új földrajzi helyváitoztatás csak telephely szintủ vizsgálattal lenne bizonyítható.

${ }^{3}$ A szakirodalomban ismert a nemzetközi töke érdeklödése elöször az olcsó munkaeröt, mint telepítési tényezőt keresi, majd halad más országba, mert ebböl kínálat van. Egy stratégiailag más fázist jelent az, ha a telephelyválasztás a képzett munkaeröre épül. Az előbbi eset új földrajzi helyet jelent, a második a helyi tapasztalatra épül és sajátos tevékenység fejlesztésére fektet be. Ritkábban történik meg, hogy új helyen speciális tevékenység kerül fejlesztésre. Ilyenek a Szilícium völgyek, a tudásgyárak és a fejlesztési helyek. Az utóbbiakat az anyaország stratégiai célból magánál tartja.

${ }^{4}$ Ezzel a megállapítással úgy lehet egyetérteni, hogy a földrajzi elỏnybe bejön egy új változó: a kapcsolałi lehetőség. Képzeljük el, hogy kevésbé jó földrajzi fekvés többfelé történő elágazási lehetôséggel rendelkezik. Ez a helyzet a kereslet-kínálat térbeli terjedését kedvezōen befolyásolja.

${ }^{5}$ A városi fejlődésben, ebben a szakaszban tapasztaljuk a termelési egységek kitelepülését és a döntési, információs és szolgáltatási munkák központban maradását. Ezt a szétválást az ingatlan árak is gyorsítják, mert a területigényes munkák a perifériára kerülnek, kisebb kék galléros ingázással lehet számolni, ami a cégek utazási költségtérítési kiadásait is csökkenti.

${ }^{6}$ A beszálítói rendszer kialakulása során az anyacégek arra törekednek, hogy a részegységtermelök árait leszorítsák, a hálózati munkát virtuálissá tegyék és a technológia átadásăhoz és a nemzetközi szabványok megtartásához szükséges gépi fejlesztéseket, környezetvédelmi kiadásokat a kisvállalkozások számlájára valósítsák meg. Ez az anyavállalattal kialakult korábbi függőséget növeli, és rákényszeríti a nemzetközi szintü felzárkózásra.

${ }^{7}$ Az e-business jogi és adózási szabályozásának legtöbb vitája arról szól, hogy a nemzeti szabályozások határai mennyire felelnek meg, pl. a kiszállított termék közigazgatási határának. A telephely, a megrendelés, a kiszállitás célterületei akár eltérö kontinenseken is lehetnek.

${ }^{8}$ Hazai vizsgálataink során, pl. nem találtunk magyarázatot arra, hogy a bizsu- és drágakö-feldolgozás miért futott fel, majd szinte tünt el egyes években és egyes térségekben.

9 Nem volt eredményes az öko-manegementben ismert fokozatok alkalmazása „Mondd meg, bízzál bennem, és mutasd meg."

${ }^{10}$ A vizsgálat Jeney-Szabó (2001) A magyar ipar a specializációs és koncentrációs indexek tükrében az 1990-es években címủ munkáját dolgozta tovább, amelyben részletesebb betekintést nyerhetünk a honi ipar rendszerváltás óta bekövetkezett általános mennyiségi és minőségi átalakulásába. Ezúttal azonban elsősorban a specializációs és koncentrációs számítások eredményeinek összefüggéseire helyezzük a hangsúlyt.

${ }^{11}$ Ágazatok: Bányászat; Élelmiszeripar, ital és dohánytermék; Textília, ruházat és börtermék; Fa-, papír és nyomdatermék; Vegyipar; Nemfémes ásványi termék; Kohászat és fémfeldolgozás; Gépipar; Egyéb feldolgozóipari termék; Villamosenergia-, gáz-, hö- és vízellátás (továbbiakban energiaipar).

${ }^{12}$ Az idöintervallum megválasztásának oka, hogy ebben a periódusban egyeznek minden szempontbół (ágazati rendszer [NACE] a mutatók, így összehasonlításra alkalmasak. 
Rédei Mária - Jakobi Ákos - Jeney László :

Regionális specializáció és a feldolgozóipari tevékenység változása.

Tér és Társadalom 16. évf. 2002/4. 87-108. p.

${ }^{13} \mathrm{Az}$ index értéke 0 és $\$ között lehet. Minél nagyobb az érték, annál nagyobb az abszolút specializáció vagy koncentráció mértéke.

${ }^{14} \mathrm{Az}$ index értéke 0 és 2 közöu lehet. Minél nagyobb az érték, annál nagyobb a relatív specializáció vagy koncentráció mértéke.

15 A Herfindahl index nagyon hasonlít a Gini-Hirschman-féle koncentrációs arány képletére (1., pl. Nemes Nagy 1977). Ez utóbbi módszer által kapott eredmény négyzete egyenlő a Herfindahl index révén kiszámított eredménnyel. A Diszimilaritási index szintén hasonlít egy gyakorta használt formulára, a Hoover-féle terưleti egyenlötlenségi mutatóra (1. uo.). Ez utóbbi képlet alapján számított érték kétszerese egyenló a Diszimilaritási index által produkált értékkel.

${ }^{16} \mathrm{i}=$ iparág, $\mathrm{j}=$ megye

$S_{i j}{ }^{S}=j$ megye i iparăgának részesedése j megye teljes ipari foglalkoztatottaiból (illetve értékesítéséböl. exportértékesítéséböl)

$\mathrm{S}_{1}=\mathrm{i}$ iparág részesedése az országban az ország teljes ipari foglalkoztatottaiból (illetve értékesítéséböl, exportértékesitéséböl)

$\mathrm{S}_{i j}{ }^{\mathrm{C}}=\mathrm{j}$ megye $\mathrm{i}$ iparágának részesedése $\mathrm{i}$ iparág teljes (országos) foglalkoztatottaiból (illetve értékesítéséböl, exportértékesítéséböl)

$\mathrm{S}_{\mathrm{j}}=\mathrm{j}$ megye részesedése az országban az ország teljes ipari foglalkoztatottaiból (illetve értékesítéséböl, exportértékesítéséböl)

\section{Irodalom}

Amiti, M. (1997) Specialisation Patterns in Europe. - Centre for Econonic Performance, Discussion Paper. London School of Economics. No. 363.

Bernek Á.(2000) A globális világ új gazdaságföldrajza. - Tér és Társadalom. 4. 87-107. o.

Brulhart-Torstensson (1996) Regional Integration. Scale economies and Industry Location in the European Union. - Centre for Economic Policy Research paper. No. 1435.

Enyedi Gy. (1996) Regionális folyamatok és térszerkezet Magyarországon. (SZÓ-KÉP)

Greenway, D.-Hine, R.C. (1991) Intra-Industry Specialisation, Trade Expansion and Adjustment in the European Economic Space. - Journal of Common Market Studies. 6. 603-22. o.

Hanson, G.H. (1996) 'Economic integration, intra-industry trade, and frontier regions'. - Europectn Economic Review. Vol. 40. 941-949. o.

Hine, R.C. (1990) Economic Integration and Inter-industry Specialisation. - CREDIT Research Paper. University of Nottingham. 89/6.

Inotai (1998) Technológiai versenyképesség. OMFB-MTA VKI, Budapest.

Jakab-Kovács-Oszlay (2000) Hová tart a külkereskedelmi integrácio? MNB Füzetek/1.

Jeney L.-Szabó P. (2001) A magyar ipar a specializációs és koncentrációs indexek tükrében az 1990-es években. - A Magyar Földrajzi Konferencia tudományos közlenlényei. CD-ROM. SZTE TTK. Szeged.

Krugman, P. (1991) Geography and Trade. MIT Press, Cambridge.

Lengyel 1. (2000) Porter-rombusz: a regionális gazdaságfejlesztési stratégiák alapmodellje. - Tér és Társadalom. 4. 39-86. o.

Mariotti (2001) Firm migration patterns in the Netherland and in the United Kingdom. ERSA conference, Zagreb.

Nemes Nagy J. (szerk.) (1977) Regionális gazdaságfóldrajzi gyakorlatok. Tankönyvkiadó, Budapest.

Nemes Nagy J. (2000) The new regional structure in Hungary. - Petrakos, G.-Maier, G.-Gorzelak, G. (eds.) Integration and Transition in Europe. Routledge, London.

Rédei M. (2002) Információs és tudás társadalom. - Bernek Á. (szerk.) A globális világ politikai fôldrajza. Nemzeti Tankönyvkiadó, Budapest. 330-355. o.

UNIDO (2000) Regional Forum UNIDO on Industrial Cooperation and Parnership in Central and eastern Europe and NIS CD.

Sassen, S. (1996) Transnational economy-transnational mobility. IMES, Brussels. 